\title{
Effect of Weedy Annuals on the Survival and Growth of Transplants Under Arid Conditions
}

\author{
GORDON A. VAN EPPS AND CYRUS M. MCKELL
}

\begin{abstract}
A plant establishment study was conducted in the oil shale region of northeastern Utah where annual rainfall averages 200 $\mathrm{mm}$. Treatments consisted of annual weed removal for 2 years, for 1 year, and no removal to test the impact of competition on survival of bareroot and container-grown transplants. Competition had a major negative effect on the survival and growth of fourwing saltbush (Atriplex canescens), winterfat (Ceratoides lanata), prostrate summer cypress (Kochia prostrata), and russian wildrye (Elymus junceus). At the end of 4 growing seasons only $21 \%$ of the plants survived under normal site competition compared to $84 \%$ survival with 2 years of weed removal. The area of plant canopy under the influence of full competition averaged 0.95 $\mathrm{dm}^{2}$ as compared with $4.03 \mathrm{dm}^{2}$ where competition was absent for 2 years for the same period.
\end{abstract}

Plant competition for soil water generally is extreme in arid regions. A dense stand of annual vegetation such as cheatgrass (Bromus tectorum), halogeton (Halogeton glomeratus) or Russian thistle (Salsola pestifer) may compete so intensely with seeded or transplanted species as to inhibit their establishment or reduce their vigor sufficiently to limit survival and growth. Whenever surface disturbance occurs, the invasion of annual species is especially acute. Thus, any manipulation of the vegetation or soil surface that increases water accumulation and retention for beneficial use by specific desirable plants would be advantageous.

Numerous researchers studying plant establishment under the constraints of stress environments have alluded to the need for controlling plant competition. Several of these are Holmgren (1956), Hubbard (1957), and Sanderson et al. (1963) in the establishment and growth of bitterbrush (Purshia tridentata), Guinta et al. (1975), Van Epps and McKell (1977), and staff of the Institute for Land Rehabilitation (1979) in establishing several shrub species, and Schubert (1977) in ponderosa pine (Pinus ponderosa) regeneration. Springfield (1970) found that grass competition adversely affected the survival of fourwing saltbush (Atriplex canescens) transplants in New Mexico. Studies in California (Clary 1974) indicated the need for controlling competition for 2 or more years.

In direct seeding, Plummer et al. (1968) specified that competition must be low enough for desired species to become firmly established. Several methods of removing unwanted vegetation were described. Keller (1978) emphasized the importance of reducing the annual grasses and forbs for successful range seeding in the sagebrush ecosystem. Evans and Young (1977) developed a herbicide revegetation system that provides management techniques to control competition in sagebrush (Artemisia) cheatgrass range-

\footnotetext{
Authors are associate professor (stationed at Snow Field Station, Ephraim, Utah 84627) and professor, Range Science Department and Institute for Land Rehabilitalion. Utah State University. Logan 84322.

Authors wish to ack nowledge the assistance of Jerry Barker, G. Brock Benson and Eric Christensen. The work was supported by White River Shale Project (Sunoco Energy Development Company), Utah Agricultural Experiment Station and Snow College.

Manuscript received January 12, 1982.
}

lands. Whereas many revegetation studies have been carried out in areas receiving more than $30 \mathrm{~cm}$ of precipitation, this paper considers the effect of plant competition on the survival and growth of transplants in an area receiving less than $23 \mathrm{~cm}$ of precipitation.

\section{Methods}

The study was conducted in the oil shale region of northeastern Utah in an area of less than $225 \mathrm{~mm}$ of rainfall. Natural vegetation surrounding the research site is dominated by shadescale (Atriplex confertifolia) with sagebrush (Artemisia tridentata spp wyomingensis) and greasewood (Sarcobatus vermiculatus) appearing in areas of deeper soils.

The study site was on a deep alluvial sandy loam fill which extended to a depth greater than $120 \mathrm{~cm}$. A soil survey in 1977 described the soil as a loamy-skeletal, mixed, frigid, calciorthid, aridisol.

All planting stock was grown originally in containers in the greenhouse to provide uniformity among plants. The containers measured $6 \times 6 \times 15 \mathrm{~cm}$. Plants were grown in a mixture of soil, sand, and peat moss of equal volume for approximately 7 months prior to field planting. At the time of planting they were divided into those to be planted as container stock and those designated as bare root transplants. The latter were removed from the container and the soil was shaken from the roots. Thus planting materials were similar in genetic and developmental aspects. However, this method of obtaining bare root plants yielded transplants with a greater fibrous root mass than those generally grown as typical bare-root stock.

The planting site was partially prepared during late summer of 1976 after seeds had been shed, by removing all annual and perennial plant growth, leaving the site in a fallowed condition for winter moisture accumulation. The entire site was weeded for annual seedlings by manual cultivation in the following spring leaving a uniform loose shallow soil mulch. Prior to planting on April 5, 1977 , the site was fenced for rabbit and rodent control. The soil was moist from a wet snow storm 2 days earlier. Three competition treatments were established on $3 \times 5.5-\mathrm{m}$ plots: (1) a cont rol where all indigenous seedlings were allowed to grow naturally following the planting; (2) 1 year of clean cultivation; and (3) 2 years of clean cultivation.

The 4 transplanted species were fourwing saltbush, (Atriplex canescens, ATCA), winterfat (Ceratoides lanata, CELA), prostrate summer cypress (Kochia prostrata, KOPR), and Russian wildrye (Elymus junceus ELJU). Four plants of each species were planted as bare-root and 4 as container-grown plants on a $70 \times$ $70-\mathrm{cm}$ grid in each of the 3 competition treatments. There were 4 replications. All plants received only $I$ liter of water following planting though results from other studies in the area have been inconclusive as to its value. By May 19, the planting site was rather uniformily covered with a dense seedling growth of halogeton, Russian thistle and limited numbers of cheatgrass plants. All weed seedlings in the 1 and 2-year clean cultivation treatments were 
manually hoed or pulled at this time from around and between the transplants leaving a loose soil surface mulch. Both treatments were kept free of other plant growth for the remainder of the 1977 growing season and then in 1978 only the 2-year clean cultivation plots were maintained free from other plant competition. Yearly precipitation averaged $230 \mathrm{~mm}$ over the 3 years of the study.

Survival, plant condition, plant height, and cover data were obtained in the fall of each year. Plant condition was determined by visual examination, using a 3-numeral scale -0 for dead plants, 1 indicating that a plant was in poor condition, and a 2 indicating a vigorous, healthy plant. Plant height was mcasurcd from ground level to tip of the highest vegetative stem. Crown cover was estimated using a $.25-\mathrm{m}$ frame with $10-\mathrm{cm}$ squares marked off in units.

Data were statistically analyzed at the end of the second year using the Duncan multiple range test at the $1 \%$ level. However, to follow the trends in survival and growth beyond the planned duration of the study, observations were made for 2 additional years.

\section{Results}

Effects of the 3 competition levels on survival were significant $(P<0.01)$ among treatments a veraged over all species. At the end of the second growing season, corresponding to the end of the treatment years, average survival of all species regardless of the type of plant material used was $47 \%$ for the control, $72 \%$ for 1 year of clean cultivation, and $91 \%$ for 2 years of clean cultivation. Two years later at the end of the fourth growing season, survival in the same treatment order was 21,55 , and $84 \%$. Two years of clean cultivation were 4 times more effective for plant survival than when plants were exposed to natural competition.

A comparison of planting materials in relation to survival indicated significance $(P<0.01)$. After 2 years bare-root stock showed a $64 \%$ survival, compared with $76 \%$ for the container stock. Two years later the survival was 49 and $57 \%$, respectively.

The trend in transplant survival over 4 growing seasons in relation to the 3 competition levels and 2 types of plant materials appeared to become stable after 3 years (Fig. 1). Plant survival rapidly decreased when the annual plants in the 1 -year clean cultivation treatment were allowed to compete for moisture during the second and third growing seasons, which indicated that these plants had not become fully established during the first few years following field planting. Plant mortality was highest for plants growing under natural competition, although the greatest losses occurred during the first growing season, especially those planted as bare-root stock. Relatively few plants died during the fourth growing season under 2 years of clean cultivation. By this time plants in the other 2 levels of competition appeared to have already reached an adjustment to the moisture stress environment.

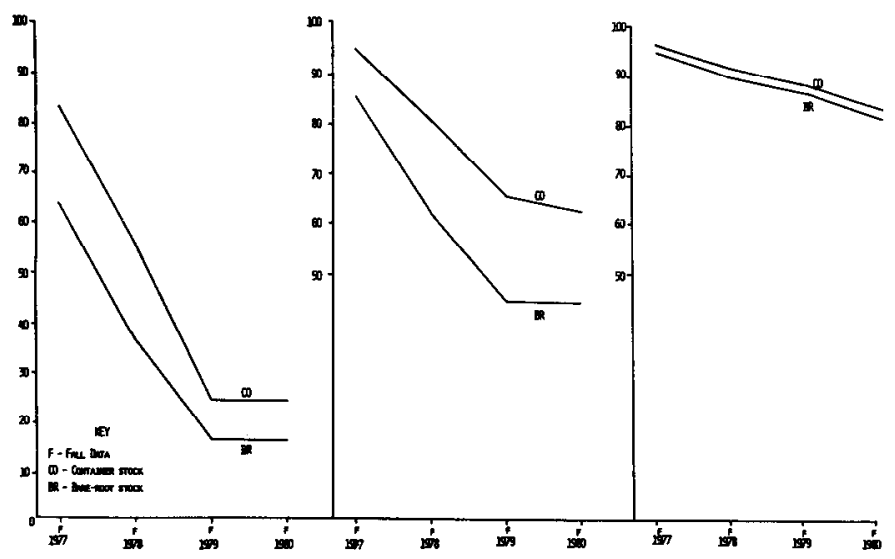

Fig. 1. Percent survival trend comparing three competition levels and 2 methods of planting ( $B B=$ bare-root and $C O$-container transplants) over 4 growing seasons. Competition removal treatments, reading from left to right were; control 1 year removal, 2 years removal.

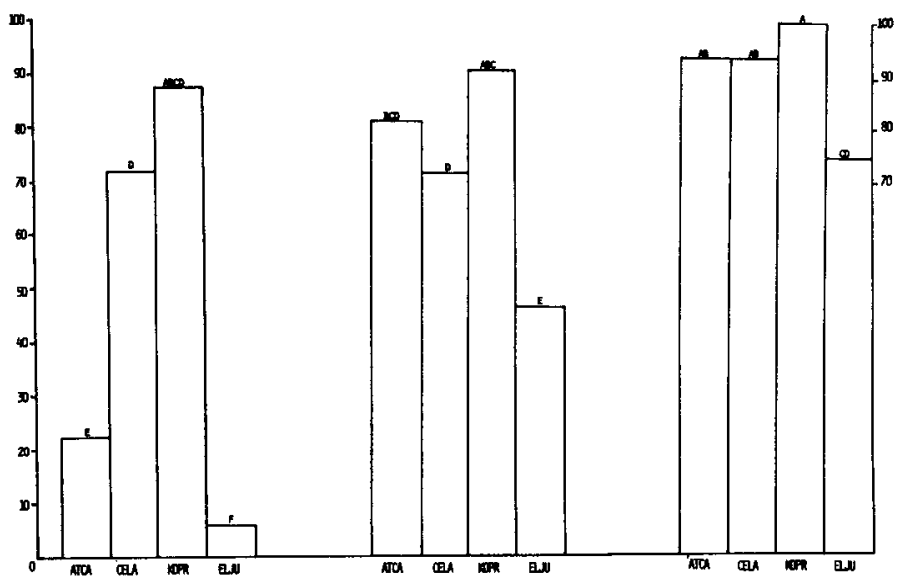

Fig. 2. Percent survival comprison of four plant species under 3 competition levels following 2 growing seasons. Competition removal treatments, reading from left to right were control, 1 year removal, 2 years removal.

Plant losses during the first few years of establishment must be expected as a normal consequence whether from artificial planting of transplants or from natural establishment especially where competition is a factor. Data from the Desert Experimental Range (West 1979) showed a large loss of nat ural seedlings during the first 2 years followed by a subsequent leveling off in plant mortality.

Survival of bare-root and container-grown plants was statistically different under natural competition and 1 year of clean cultivation. Container stock showed a higher survival rate in the fall for each of the 4 growing seasons (Fig. 1). The difference in survival between planting methods was less for 2 years of clean cultivation than for the other 2 levels of competition. Containergrown stock showed a survival rate of $25 \%$ under natural competition, $64 \%$ under 1 -year competition removal, and $85 \%$ for 2 years of clean cultivation at the end of 4 growing seasons. In contrast, bare-root stock survival was $17 \%$ under nat ural competition, $45 \%$ under 1 year of clean cultivation, and $83 \%$ under 2 years of clean cultivation.

Survival of the various species in relation to the competition removal treatments at the close of the second growing season varied significantly $(P<0.01)$ (Table 1 and Fig. 2). Prostrate summer cypress appeared to be more capable of withstanding the detrimental effects of plant competition during the first 2 years of establishment than the other 3 species. Russian wildrye was the least capable. Annual plant competition had a negative effect on the survival of fourwing saltbush when not controlled for at least 1 year (Fig. 3). Two years of competition suppression appeared to increase the survival of winterfat and russian wildrye grass greatly. 
Table 1. Summary of fall data comparing treatments and species during the 4 years of the study. Means followed with the same letter are not significantly different at $P<0.01$ value for each variable and within each factor.

\begin{tabular}{|c|c|c|c|c|c|c|c|c|c|c|}
\hline \multirow[b]{2}{*}{ Species ${ }^{I}$} & \multirow[b]{2}{*}{ Year } & \multicolumn{3}{|c|}{ Survival treatments } & \multicolumn{3}{|c|}{ Height treatments } & \multicolumn{3}{|c|}{$\begin{array}{c}\text { Ground covered by plant canopy } \\
\text { treatments }\end{array}$} \\
\hline & & $\begin{array}{c}\text { Control } \\
(\%)\end{array}$ & $\begin{array}{l}1 \text { year } \\
(\%)\end{array}$ & $\begin{array}{l}2 \text { year } \\
(\%)\end{array}$ & $\begin{array}{l}\text { Control } \\
\text { (cm) }\end{array}$ & $\begin{array}{c}1 \text { year } \\
(\mathrm{cm})\end{array}$ & $\begin{array}{l}2 \text { year } \\
(\mathrm{cm})\end{array}$ & $\begin{array}{l}\text { Control } \\
\left(\mathrm{dm}^{2}\right)\end{array}$ & $\begin{array}{l}1 \text { year } \\
\left(\mathrm{dm}^{2}\right)\end{array}$ & $\begin{array}{r}2 \text { year } \\
\left(\mathrm{dm}^{2}\right)\end{array}$ \\
\hline ATCA & $\begin{array}{l}1977 \\
1978 \\
1979 \\
1980\end{array}$ & $\begin{array}{c}72 \\
22 \mathrm{e} \\
7 \\
7\end{array}$ & $\begin{array}{l}91 \\
81 \mathrm{bcd} \\
78 \\
78\end{array}$ & $\begin{array}{l}94 \\
91 \mathrm{ab} \\
91 \\
91\end{array}$ & $\begin{array}{l}6 \\
2 \mathrm{fg} \\
2 \\
2\end{array}$ & $\begin{array}{l}22 \\
27 \mathrm{bc} \\
35 \\
31\end{array}$ & $\begin{array}{l}22 \\
38 \mathrm{ab} \\
44 \\
36\end{array}$ & $\begin{array}{l}-\overline{0} \\
.07 \mathrm{f} \\
.06 \\
.08\end{array}$ & $\begin{array}{l}-\overline{50} \mathrm{bc} \\
4.70 \\
4.41\end{array}$ & $\begin{array}{l}- \\
8.56 \\
8.42 \\
6.33\end{array}$ \\
\hline CEIA & $\begin{array}{l}1977 \\
1978 \\
1979 \\
1980\end{array}$ & $\begin{array}{c}94 \\
72 \mathrm{~d} \\
9 \\
9\end{array}$ & $\begin{array}{l}87 \\
69 \mathrm{~d} \\
31 \\
29\end{array}$ & $\begin{array}{l}97 \\
94 a b \\
85 \\
79\end{array}$ & $\begin{array}{l}13 \\
11 \mathrm{ef} \\
3 \\
2\end{array}$ & $\begin{array}{l}17 \\
17 \mathrm{de} \\
9 \\
7\end{array}$ & $\begin{array}{l}18 \\
35 a b c \\
34 \\
24\end{array}$ & $\begin{array}{l}.37 \text { ef } \\
.19 \\
.05\end{array}$ & $\begin{array}{l}1 . \overline{73 d e f} \\
.59 \\
.45\end{array}$ & $\begin{array}{l}- \\
3.50 \mathrm{cde} \\
3.94 \\
2.63\end{array}$ \\
\hline KOPR & $\begin{array}{l}1977 \\
1978 \\
1979 \\
1980\end{array}$ & $\begin{array}{l}100 \\
88 \mathrm{abcd} \\
63 \\
63\end{array}$ & $\begin{array}{l}100 \\
91 \mathrm{abc} \\
75 \\
75\end{array}$ & $\begin{array}{l}100 \\
100 \mathrm{a} \\
100 \\
87\end{array}$ & $\begin{array}{l}23 \\
24 \mathrm{~cd} \\
33 \\
19\end{array}$ & $\begin{array}{l}39 \\
25 \mathrm{~cd} \\
35 \\
20\end{array}$ & $\begin{array}{l}39 \\
44 a \\
48 \\
22\end{array}$ & $\begin{array}{l}1 . \overline{50 \mathrm{ef}} \\
5.78 \\
3.53\end{array}$ & $\begin{array}{l}-\overline{39} \mathrm{~cd} \\
7.77 \\
4.61\end{array}$ & $\begin{array}{c}- \\
13.26 \mathrm{a} \\
13.78 \\
4.63\end{array}$ \\
\hline ELJU & $\begin{array}{l}1977 \\
1978 \\
1979 \\
1980\end{array}$ & $\begin{array}{c}28 \\
7 \text { f } \\
7 \\
7\end{array}$ & $\begin{array}{l}85 \\
47 \text { ef } \\
37 \\
37\end{array}$ & $\begin{array}{l}94 \\
81 \mathrm{~cd} \\
81 \\
81\end{array}$ & $\begin{array}{l}<1 \\
<19 \\
<1 \\
1\end{array}$ & $\begin{array}{c}8 \\
<19 \\
4 \\
7\end{array}$ & $\begin{array}{l}6 \\
10 \mathrm{~g} \\
16 \\
15\end{array}$ & $\begin{array}{l}\overline{.01 f} \\
.05 \\
.13\end{array}$ & $\begin{array}{l}-\overline{1 f} \\
.30 \\
.82\end{array}$ & $\begin{array}{l}- \\
.15 f \\
2.17 \\
2.54\end{array}$ \\
\hline
\end{tabular}

IATCA - Fourwing saltbush

CELA - Winterfat

KOPR - Prostrate summer cypress

ELJU - Russian wildrye grass

2 No calculations were made on plant cover for 1977

On a scale of 0 to 2 , uncontrolled competition resulted in an average plant condition rating of $0.55 ; 1$ year of clean cultivation, 0.95 ; and 2 years of clean cultivation, 1.73 . Two years later in the fall of 1980 plant vigor was $0.42,1.05$ and 1.67 respectively. There was no difference in plant condition rating between types of plant materials. Plant condition is a good indicator measurement as to the effect of the treatments on a plant's vitality and growth including its reproduction.

The interaction of competition treatments and species on plant condition was highly significant $(P<0.01)$. A significant $(P<0.01)$ difference was observed between the effects of 2 years of clean cultivation and the 2 competition levels at the end of the second growing season. Although not significant there was a generally observed difference in plant condition between plants grown in the control treatment and those in the 1-year clean cultivation. The average plant conditions of the 3 shrubs was uniformly good but the grass plants were poor in comparison. There was no significant difference in average plant condition of bare root and container grown plants.

Plant growth expressed as ground cover was highly significant $(P<0.01)$ in the categories of competition treatments, planting materials and the interaction between treatments and species. The total area of ground cover by planted species canopy where no competition was removed averaged $0.49 \mathrm{dm}^{2}$ at the end of the first 2 growing seasons. This compares with $2.66 \mathrm{dm}^{2}$ for 1 year of clean cultivation and $6.37 \mathrm{dm}^{2}$ for 2 years of clean cultivation. Plant cover of the 4 species showed various restrictions in relation to the 3 levels of plant condition (Table 1).

Fourwing saltbush, winterfat, and prostrate summer cypress transplants had a significantly larger cover a rea when grown for 2 years without competition than those under uncontrolled competition. The difference in size of plants in 1978 where subjected to the 2 competition treatments was many-fold. Russian wildrye, being a grass that goes dormant under these arid conditions, appears smaller in the fall than in the spring. Russian wildrye produced numerous seed heads in the spring when grown for 2 years without competition as compared with few seed heads under uncontrolled competition.

In the case of plant height there was a significant interaction $(P<0.01)$. At the end of the second growing season, the mean height for plants in the control treatment was $10 \mathrm{~cm}$, those in the 1 -year clean cultivation treatment were $18 \mathrm{~cm}$, and those in the 2 years of clean cultivation treatment were $32 \mathrm{~cm}$. This compared with a height of 6,16 , and $24 \mathrm{~cm}$ for each treatment, respectively, at the end of the fourth growing season. Two years of clean cultivation resulted in an increase in plant height 4 times over the control after 4 years. Plant height was significantly $(P>0.05)$ greater from container-grown stock at $22 \mathrm{~cm}$ as compared with bareroot stock at $19 \mathrm{~cm}$ (Table 1).

\section{Conclusions}

Intense plant competition from weedy annual species has a negative influence on the survival and growth of perennial plant species transplanted either as bare-root or container-grown stock. Plant species most likely to survive are those which can endure competition from annual plants such as prostrate summer cypress. The effects of competition reduction are generally reflected in greater plant height and cover. Plant species most likely to withstand competition are those best adapted to a site. Species poorly adapted to a site apparently are not able to respond to the improved control of competition. These studies have substantiated the early work of Holmgren (1956), Hubbard (1957) and others as to the need for controlling competition when establishing vegetation through seeding or by transplants. Improved plant establishment in arid sites appears to be possible by controlling competition of annual weedy forbs and grasses for a period of 1 or 2 years.

Three or more growing seasons may be needed to determine the permanent establishment of plants under arid conditions. Plants under uncontrolled competition appear to stabilize their survival rate by the end of the third year. Springfield (1970) reported that four wing saltbush transplants in the Southwest under no competition stabilized in survival during the fourth year following field planting, while the survival rate of those growing in competition with grass was still declining in the fifth year.

There are large variations among species as to the negative impact of plant competition on plant survival and growth. Prostrate summer cypress was noticeably more successful in its establishment success than fourwing saltbush, winterfat or Russian wildrye. 


\section{Literature Cited}

Clary, Raimond F., Jr. 1974. An evaluation of shrubs for revegetation in the Sierra Nevada Foothills and coastal range of California. Proceed. Erosion Control Symposium. Woodlake Inn, Calif. USDA-SCS and Univ. California Ext.

Evans, R.A., and J.A. Young. 1977. Weed control-revegetation systems for big sagebrush-downybrome rangelands. J. Range Manage. 30:331-336.

Giunta, B.C., D.R. Christensen, and S.B. Monsen. 1975. Interseeding shrubs in cheatgrass with a browse seeder-scalper. J. Range Manage. 28:398-402.

Holmgren, Ralph D. 1956. Competition between annuals and young bitterbrush (Purshia tridentata) in Idaho. Ecology 37:371-377.

Hubbard, Richard L. 1957. The effects of plant competition on the growth and survival of bitterbrush seedlings. J. Range Manage. 10:135-137.

Institute for Land Rehabilitation. 1979. Selection, propagation, and field establishment of native plant species on disturbed arid lands. Utah Agri. Exp. Sta. Bull. 500.
Keller, Wesley. 1978. Species and methods for seeding in the sagebrush ecosystem. The sagebrush ecosystem, a symposium. Utah State Univ. Coll. of Natur. Resources, Logan, Utah. p. 129-163.

Plummer, A.P., D.R. Christensen, and S.B. Monsen. 1968. Restoring big game range in Utah. Utah Div. of Fish and Game Pub. 68-3.

Sanderson, H.R., R.L. Hubbard, and D.W. Seecrist. 1963. Effects of grass competition on bitterbrush: second-year report. U.S. Forest Service Res. Note PSW-26.

Schubert, Gilbert H., 1977. Forest regeneration of arid lands. Proc. Soc. Amer. Forest. 1977. Nat. Conv. (Oct. 2-6, 1977, Albuquerque, N.M.) Soc. Amer. Forest. p. 82-87.

Springfield, H.W. 1970. Germination and establishment of fourwing saltbush in the southwest. USDA Forest Service Res. Pap. RM-55.

Van Epps, G.A., and C.M. McKell. 1977. Shrubs plus grass for livestock forage: a possibility. Utah Sci. 38:75-78.

West, Neil E. 1979. Survival patterns of major perennials in salt desert shrub communities of Southwestern Utah. J. Range Manage. 32:422445.

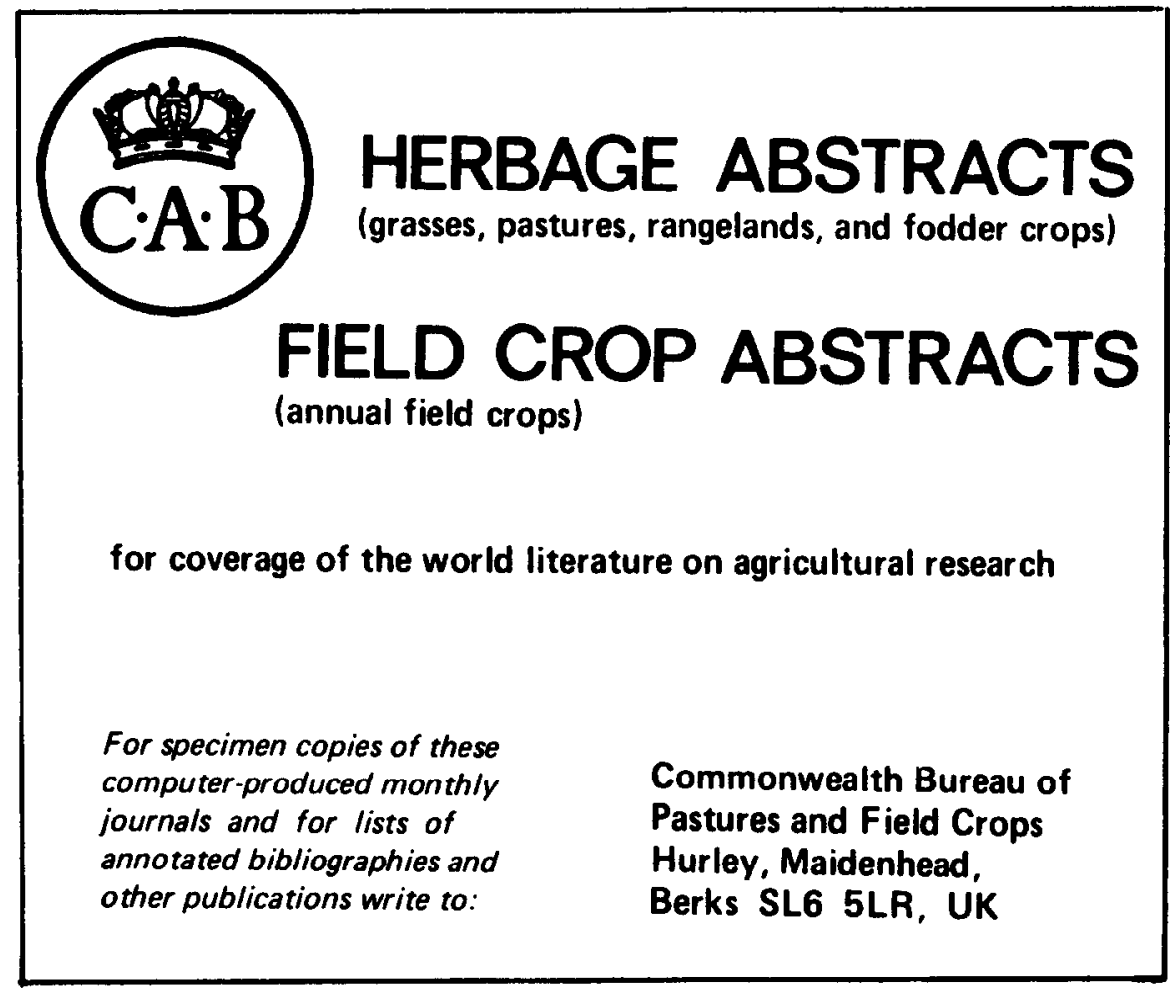

